\title{
Adsorption of Cadmium from Aqueous Solution onto Untreated Gypsum Rock Material: Equilibrium and Kinetics
}

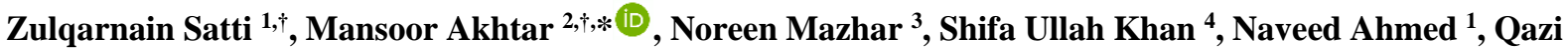 \\ Muhammad Yasir ${ }^{1}$, Muhammad Irshad ${ }^{5, *}$, Rashid Pervaiz ${ }^{6}$, Waqas Ahmad ${ }^{7}$ \\ 1 School of Geographical Sciences, Northeast Normal University, Changchun, 130024, China \\ 2 Faculty of Chemistry, Northeast Normal University, Changchun, 130024, Jilin, China \\ 3 Institute of Chemistry, University of Punjab, Quaid-e-Azam Campus, Lahore-54590, Pakistan \\ 4 School of Sino-Foreign Chemical Engineering Liaoning University of Petroleum and Chemical Technology, Fushun, \\ Liaoning, China \\ 5 Arid Land Research Center, Tottori University, Tottori, 680-0001, Japan \\ 6 Key Lab of Submarine Geosciences and Prospecting Techniques, MOE, College of Marine Geosciences, Ocean University \\ of China, Qingdao 266100, China \\ 7 College of Veterinary and Animal Sciences (CVAS), Narowal (Sub-campus), University of Veterinary and Animal \\ Sciences, Lahore \\ $\dagger$ These authors contributed equally to this paper \\ * Correspondence: akt100@ nenu.edu.cn,mirshad@cuiatd.edu.pk
}

Received: 21.10.2020; Revised: 12.11.2020; Accepted: 13.11.2020; Published: 14.11.2020

\begin{abstract}
The concentration of heavy metals exceeding from certain limit may cause risk and endanger ecosystems and human health. Water receives a considerable concentration of heavy metals from different anthropogenic and natural sources. A study was carried out to investigate the effectiveness of rock materials on the reduction of $\mathrm{Cd}$ from contaminated water. For this purpose, gypsum was applied to the contaminated water. The findings of the present study concluded that the adsorption of $\mathrm{Cd}$ was higher in finer rock material rather than coarse material due to the surface area. The finer grains contained a greater surface area than coarse grains. The isotherms of adsorption were constructed according to the mathematical linearization. The best-fitting followed the Freundlich and DubininRadushkevich models, describing multilayer adsorption and chemical interaction, also confirmed by the pseudo-second-order kinetic model. The material removed a greater amount of $\mathrm{Cd}$ from contaminated water, especially at an increasing application rate.
\end{abstract}

Keywords: adsorbent material; cadmium; contaminated water; gypsum.

(C) 2020 by the authors. This article is an open-access article distributed under the terms and conditions of the Creative Commons Attribution (CC BY) license (https://creativecommons.org/licenses/by/4.0/).

\section{Introduction}

Wastewater has been originating from industries, municipal areas that contain heavy metals. These metals are hazardous for water resources, agriculture, ecosystem, and the human population [1]. The analysis to understand systems and technologies for the removal of heavy metals is crucial to resolve this issue for a sustainable ecosystem. Heavy metals are fairly mobile in the soils and primarily present as an organically bound, exchangeable, and watersoluble species [2]. Most heavy metals produce toxicity, even permit concentrations approximately $0.1-0.3 \mathrm{mg} \mathrm{L}^{-1}[3,4]$. Heavy metals have been considered non-biodegradable hence can be accumulated in the living tissues, causing various diseases and disorders. It is 
imperative to remove before discharge from the origin. Their harmful effects were brought into consideration when human, and marine life destruction was being noticed, including the aesthetic property of water. Wastewaters need to be treated before discharge into the environment for the protection of numerous species, including humans [5-10]. Basically, adsorption is a mass transfer process in which a substance is transferred from the liquid phase into a solid surface and becomes bound with physical and/or chemical interactions $[6,7]$. The higher adsorption capacity and surface reactivity, adsorption using activated carbon can remove metals due to higher surface area such as Ni (II) [11-16] Cr (VI) and Cd (II).

$\mathrm{Cd}$ (II) belongs to a group of hazardous heavy metal that exists in the effluent, produced via metal finishing industry [9] (e.g., electroplating), battery industry, and paint industry. Cadmium (Cd (II), zinc ( $\mathrm{Zn})$, copper $(\mathrm{Cu})$, nickel $(\mathrm{Ni})$, lead $(\mathrm{Pb})$, mercury $(\mathrm{Hg})$, and chromium $(\mathrm{Cr})$ are often detected in industrial wastewaters. They originate from metal plating, mining activities, smelting, battery manufacture, tanneries, petroleum refining, paint manufacture, pesticides, pigment manufacture, printing, and photographic industries [10, 11]. Adsorption is figured out as the most effective and economical method for $\mathrm{Cd}$ (II) containing naturally available material. This material can be efficiently used for the removal of Cd (II) from aqueous solution [17-27]. Adsorption was considered one of the physicochemical treatment phenomena that can be effective in removing heavy metals from the aqueous solutions. According to [13, 32], an adsorbent is cheap or low-cost if it persists abundant in nature. Moreover, it does not require sophisticated instruments and machinery for excavation. Recently, several studies have been conducted on soil heavy-metal pollution from various anthropogenic sources like Industrial wastes [28-38] or mining activity [17, 22].

The use of different materials might be beneficial for immobilizing heavy metals in polluted soil. Previously, many studies have been conducted to determine the use of different materials to stabilize heavy metals in soil. In contrast, limited studies recognized the effectiveness of different minerals to reduce their concentrations in polluted water [39-45]. There is a lack of reliable information on the removal of heavy metals from contaminated water by effective rock material. The effectiveness of rock material to ameliorate heavy metals from polluted water was partially identified, and the research question regarding competitive retention of $\mathrm{Cd}$ onto these minerals was not properly addressed [46-51]. The aim of the present analysis is to investigate the effectiveness of rock materials for the reduction of $\mathrm{Cd}$ from contaminated water. So, it represents sustainable management with high applicability and minimum environmental impact

\section{Materials and Methods}

The rocks of gypsum (CaSO4) were sampled from geologic formations (Abbottabad) with a geologic hammer and kept in a polythene bag for laboratory in (NE-SW) direction. Later, rock samples were washed with deionized water and put in furnace around 24 hours (h) at 90 ${ }^{\circ} \mathrm{C}$ for dryness. Powdered rock samples were weighed out as per the specifications of the batch experimentation and kept in a moisture-free environment.

\subsection{Chemicals.}

The chemicals which were used in this study were Cadmium chloride tetrahydrate (642045, Sigma-Aldrich), NaOH (221465, Sigma-Aldrich), and $\mathrm{HNO}_{3}$ (225711, SigmaAldrich). 


\subsection{Analysis.}

Morphological characterization of the gypsum rocks was obtained via SEM (scanning electron microscopy). The model of equipment was scanning electron microscope FEI Quanta 200 , operating at $30 \mathrm{kV}$.

To characterize the load on the adsorbent's surface, the point of zero charges (pHPzc) of the gypsum rocks was identified. The process involved adding $50 \mathrm{mg}$ of a gypsum rock sample in $50 \mathrm{~mL}$ aqueous potassium chloride at $0.05-0.5 \mathrm{~mol} \mathrm{~L}^{-1}$, with initial $\mathrm{pH}$ values ranging from 2.0 to 10.0. Solutions were stirred for $24 \mathrm{~h}$ at $200 \mathrm{rpm}$ and $25^{\circ} \mathrm{C}$. At the end of this period, the final $\mathrm{pH}$ variation as a function of the initial $\mathrm{pH}$; the point that reached the zero value of $\mathrm{pH}$ variation corresponds to the pHPzC $[24,34]$.

\subsection{Adsorption studies.}

2.3.1. Effect of the solution's $\mathrm{pH}$ and amount of adsorbent mass.

Cd was used in solutions of $10 \mathrm{mg} \mathrm{L}^{-1}$, prepared from $\mathrm{CdCl}_{2}$ salt utilizing distilled and deionized water. The $\mathrm{pH}$ of the solution was adjusted to 5.0, 6.0, and 7.0 using Hydrochloric acid $(\mathrm{HCl})$ and Sodium hydroxide $(\mathrm{NaOH})$, both at $0.1 \mathrm{~mol} \mathrm{~L}^{-1}$. Cd ion solutions $(50 \mathrm{~mL})$ were added to the masses of gypsum rock samples, ranging from 200 to $1,200 \mathrm{mg}$ in $125 \mathrm{~mL}$ flasks. Samples were agitated at $200 \mathrm{rpm}$ for $90 \mathrm{~min}$ at $25{ }^{\circ} \mathrm{C}$. Thereafter, $10 \mathrm{~mL}$ aliquots were removed and centrifuged at 3,000 rpm (629.77 gravity) for $5 \mathrm{~min}$, for the later determination of $\mathrm{Cd}$ concentrations in solution by flame atomic absorption spectroscopy. The $\mathrm{Cd}$ amount adsorbed was determined using Equation (1):

$$
Q \mathrm{eq}=(\mathrm{Co}-\mathrm{Ceq}) / m
$$

In which $Q$ eq is the amount of metal adsorbed by adsorbent mass $\left(\mathrm{mg} \mathrm{g}^{-1}\right), C_{0}$ and $C_{\text {eq }}$ are the initial metal concentration and in the solution equilibrium $\left(\mathrm{mg} \mathrm{L}^{-1}\right)$. V is the solution volume $(\mathrm{mL})$, and $m$ the by-product mass $(\mathrm{g})$.

\subsubsection{Effect of contact time.}

The optimal contact time for maximum cadmium removal was established. The systems containing adsorbent and $\mathrm{Cd}$ solution $\left(10 \mathrm{mg} \mathrm{L}^{-1}\right)$ were stirred at $200 \mathrm{rpm}$ and $25^{\circ} \mathrm{C}$ at the time intervals: $60,120 \mathrm{~min}$.

\subsubsection{Adsorption isotherms.}

The optimal experimental conditions were adjusted for the construction of isotherms. Herein, $50 \mathrm{~mL}$ samples of the aqueous solution of $\mathrm{Cd}$ metal at different initial concentrations (10-80 mg L ${ }^{-1}$ at $\mathrm{pH} 6.0$ were transferred to conical flasks containing $300 \mathrm{mg}$ adsorbent. The system remained in agitation at $200 \mathrm{rpm}$ and $25^{\circ} \mathrm{C}$ for $60 \mathrm{~min}$.

\subsection{Desorption.}

The adsorbent material used in the adsorption isotherms was separated from the aqueous solutions via filtration method, washed in distilled and deionized water, and dried at $70{ }^{\circ} \mathrm{C}$ for $36 \mathrm{~h}$. The adsorbent mass was obtained and placed in contact with $40 \mathrm{~mL}$ of hydrochloric acid solution at $0.1 \mathrm{~mol} \mathrm{~L}^{-1}$ and then stirred at $200 \mathrm{rpm}$ around 1 hour. 


\section{Results and Discussion}

\subsection{Adsorbent characterization.}

The adsorbent capacity of the sample has been shown in Figure 1, with the magnification of 10,000. However, the irregular and heterogeneous nature of gypsum are clearly seen, which favors the adherence of metal ions in the aqueous solution.

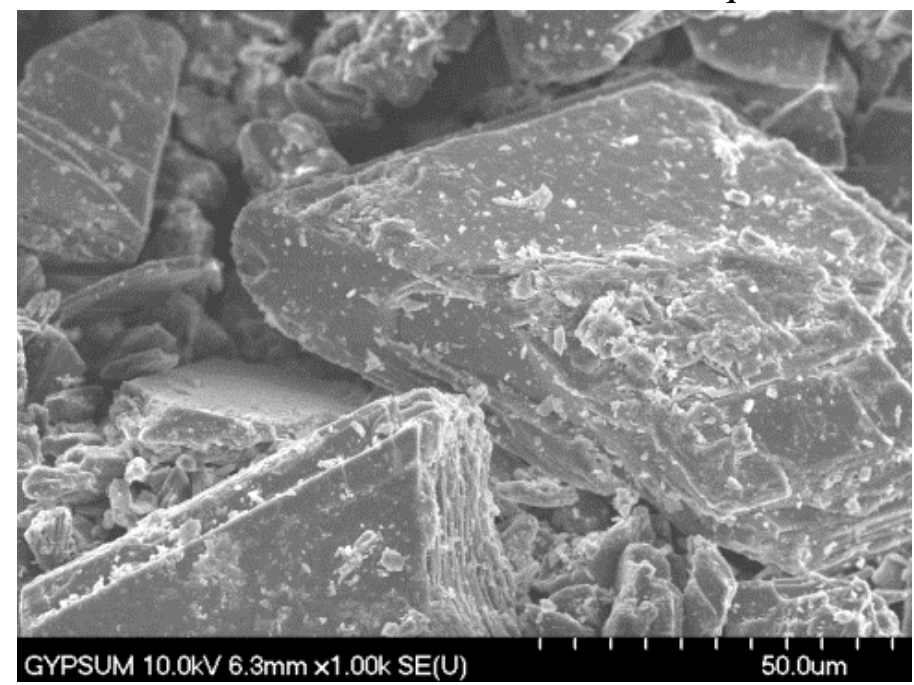

Figure 1. Scanning electron micrograph of the gypsum adsorbent enlarged 10,000 fold.

The outcome of pHPzC determination for gypsum adsorbent material is shown in (Figure 2), confirming the data obtained by also performed the pHpzC test [25].

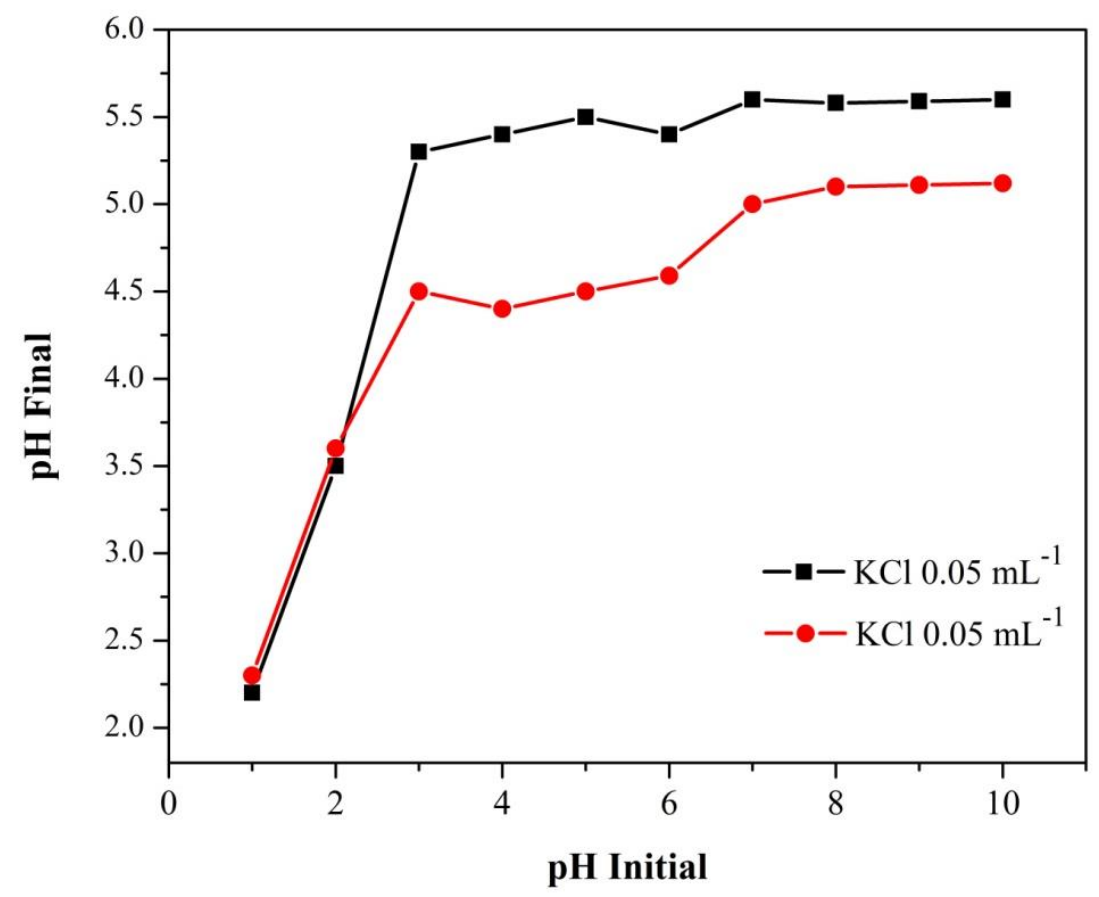

Figure 2. Experimental data for determining the $\mathrm{pH}_{\mathrm{PZC}}$ for gypsum adsorbent material.

\subsection{Adsorption study.}

\subsubsection{Effect of solution $\mathrm{pH}$ and adsorbent mass.}

The study revealed that solutions at $\mathrm{pH} 6.0$ had a higher percentage of $\mathrm{Cd}$ ion removal than at the other $\mathrm{pH}$ values. (Figure 3) confirms that the pHPZC was $\mathrm{pH} 5.5$, and showing 
adsorbent behaved in this condition as a negatively charged species. In the literature, $\mathrm{pH} 6.0$ values extensively reported in Cd adsorption [26].

The influence of the adsorbent mass on the Cd adsorption (Figure 3) shows the masses higher than $500 \mathrm{mg}$, accordingly. The percentage of adsorption was constant due to the fact that a large number of sites in the adsorbent surface are available during the early stage. Thereafter, the remaining sites are difficult to occupy due to the formation of aggregates and repulsive forces between the ions in the solid and those which are free in solution [26]. Thus, in the account of present outcomes, the adsorbent mass used in subsequent studies was $500 \mathrm{mg}$.

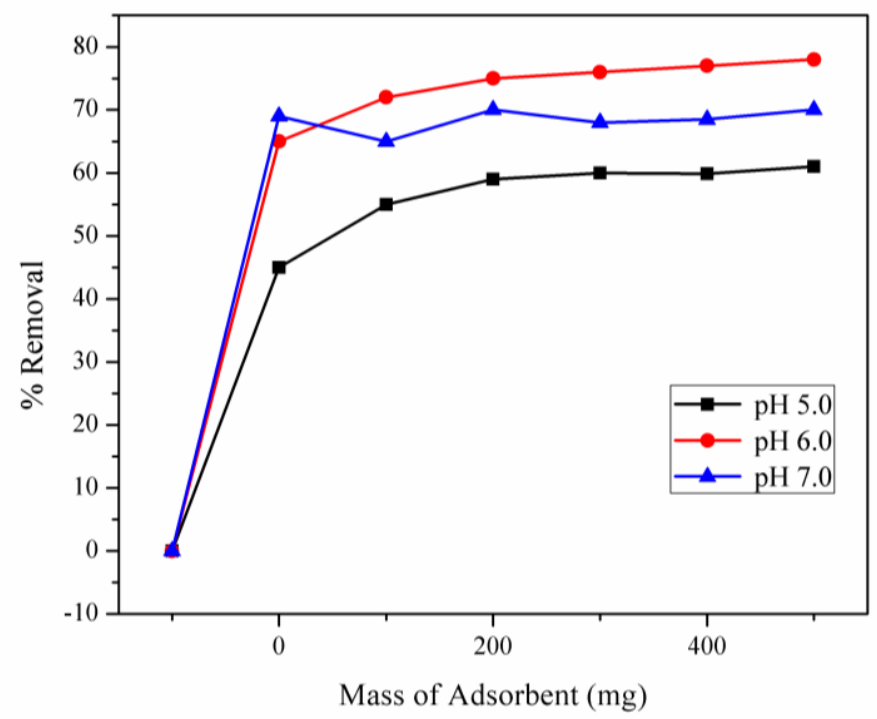

Figure 3. Percentage of Cd removal gypsum material depending on the variation of adsorbent mass and solution $\mathrm{pH}\left(C_{0} \cdot 10 \mathrm{mg} \mathrm{L}^{-1}, 90 \mathrm{~min}, 200 \mathrm{rpm} 25^{\circ} \mathrm{C}\right)$.

\subsubsection{Effect of contact time.}

The kinetics of adsorption of $\mathrm{Cd}$ on adsorbent material was analyzed using four models [38]. The pseudo-first-order model (Equation (2) illustrates that the adsorption rate is proportional to the number of sites unoccupied by the solutes [27].

$$
\log \left(Q_{\mathrm{eq}}-Q_{t}\right)=\log Q_{\mathrm{eq}}-\mathrm{K}_{1} \times t / 2.303
$$

in which $Q_{t}$ is the amount adsorbed at time $t$ (min) given in $\mathrm{mg} \mathrm{g}^{-1}, K_{1}$ is the speed constant for pseudo-first-order $\left(\mathrm{min}^{-1}\right)$.

Unlike the pseudo-first-order model (Equation (2), the pseudo-second-order model predicts the adsorption of chemical nature [25].

$$
\frac{t}{Q t}=\frac{1}{K 2 \times Q 2 e q}+\frac{1 t}{Q e q}
$$

where $K_{2}$ is the speed constant of pseudo-second-order $\left(\mathrm{g} \mathrm{mg}^{-1} \mathrm{~min}^{-1}\right)$.

The Elovich model (Equation 4) describes the kinetics of chemisorption behaviors [27]

$$
Q_{\mathrm{eq}}=A+B \ln t(4)
$$

where $A$ represents the initial speed of chemisorption, and $B$ is related to the extent of surface coverage and the chemisorption activation energy.

Although the intraparticle diffusion model was shown a higher value for the coefficient of determination $\left(\mathrm{R}^{2}\right.$ 0.904) than the pseudo-first-order (0.807) and Elovich models (0.870), 
the pseudo-second-order model demonstrates a better fit by having $Q_{\text {eq }}$ experimental values (0.902) similar to the $Q_{\text {eq }}$ calculated (0.890) and the $\mathrm{R}^{2}$ value $(0.998)$ around 1.

The kinetic study regarding question reinforces involving bibliographic study performed by the absorbency of divalent metals on various adsorbents was comprehensively described by the pseudo-second-order model, which indicates that the speed mechanism control is based on chemical adsorption [26, 28].

\subsubsection{Adsorption isotherms.}

To interpret the experimental data, four linearized isotherm models were employed. The Langmuir model (Equation (5) suggests the adsorption on a uniform surface composed of a finite number of sites containing monolayer adsorption[27]

$$
\frac{C e q}{Q e q}=\frac{1}{q m \times b}+\frac{C e q}{q m}(5)
$$

in which $q_{\mathrm{m}}$ is related to the maximum capacity of adsorption and $b$ or the Langmuir equilibrium constant $K_{\mathrm{L}}$ is related to the adsorbent-adsorbate interaction forces.

Unlike the Langmuir model, the Freundlich model (Equation (7)) describes multilayer adsorption, and it applies to heterogeneous surfaces [27].

$$
\log Q e q=\log K f+\left(\frac{1}{n}\right) \times \log C e q
$$

in which $K_{\mathrm{F}}$ is related to the adsorption capacity and $n$ to the intensity of adsorption and the adsorbent-adsorbate interaction.

The Dubinin-Radushkevich isotherm (D-R) (Equation 7) is applied to determine the adsorption energy and distinguish if the process is physical or chemical [26].

$$
\ln Q_{\mathrm{eq}}=\ln Q_{\mathrm{d}}-B_{\mathrm{d}} \times \varepsilon^{2}(7)
$$

in which $Q_{\mathrm{d}}$ is the maximum capacity of adsorption $\left(\mathrm{mol} \mathrm{g}^{-1}\right), B_{\mathrm{d}}$ expresses the adsorption energy $\left(\mathrm{mol}^{2} \mathrm{~J}^{-2}\right)$, which is linked with the average power of sorption $(E)\left(E=1 / \sqrt{ }_{-}\right.$ $2 B d) . \varepsilon$ is the Polanyi potential $\left(\varepsilon=R T \ln \left(1+1 / C_{\text {eq }}\right)\right.$ in which $R$ is the universal gas constant $(\mathrm{kJ}$ $\left.\mathrm{mol}^{-1} \mathrm{~K}^{-1}\right)$, and $T$ is the temperature $(\mathrm{K})$.

Table1. Parameters of the mathematical models of Langmuir, Freundlich, and Dubinin-Radushkevich for Gypsum adsorbent material.

\begin{tabular}{c|c} 
Parameters & Gypsum material \\
\hline Langmuir & 18.332 \\
\hline$q_{m}\left(\mathrm{mg} \mathrm{g}^{-1}\right)$ & 0.025 \\
\hline b or $\mathrm{K}_{L}\left(\mathrm{~L} \mathrm{mg}^{-1}\right)$ & 0.908 \\
\hline$R^{2}$ & \\
\hline Freundlich & 0.552 \\
\hline$K_{\mathrm{F}}\left(\mathrm{L} \mathrm{g}^{-1}\right)$ & 1.118 \\
\hline$N$ & 0.941 \\
\hline$R^{2}$ & \\
\hline Dubinin-Radushkevich & $4.4 \times 10^{4}$ \\
\hline$Q_{\mathrm{d}}\left(\mathrm{mol} \mathrm{g}^{-1}\right)$ & 8.034 \\
\hline$\left.E \mathrm{~kJ} \mathrm{~mol}^{-1}\right)$ & 0.934
\end{tabular}

The D-R and Freundlich models demonstrate the adsorption process for both adsorbents with $R^{2}$ values (Table 1). This suggests that the adsorption is influenced by the 
adsorbent surface heterogeneity, with more than one type of active site interacting with the metal, which indicates that the adsorption occurred in multilayers [29].

Regarding parameter $n$, both adsorbents showed adsorption intensity, the obtained $n$ value was greater than 1, representing beneficial and favorable adsorption [27], and mentioned (Table 1) for better understanding. The $E$ values were greater than $8 \mathrm{~kJ} \mathrm{~mol}^{-1}$, which proves that both adsorbents have a chemical interaction with the metal. Also, the values of $b$, which represents the interaction power, were higher in the carbon $\left(0.094 \mathrm{mg} \mathrm{L}^{-1}\right)$ than the biosorbent $\left(0.028 \mathrm{mg} \mathrm{L}^{-1}\right)$, which confirms the superior results of the $E$ value for the commercial adsorbent.

\subsection{Desorption.}

The proportion of $\mathrm{Cd}$ ion adsorption on the gypsum material was $76 \%$, including adsorbed amount around $79 \%$ of the ions were recovered in the desorption. These differences in adsorption and desorption between the two adsorbents can be explained with greater interaction $(b)$ and adsorption intensity $(n)$ Table 1 with the metal under consideration. These percentage values of desorption can be accepted satisfactory for possible reuse of the adsorbent material during new stages of adsorption [30].

\section{Conclusions}

Overall, the characterization of the gypsum material showed a favorable structure for adsorption. The better adsorption of $\mathrm{Cd}$ ions was found in solutions with $\mathrm{pH} 6.0$, confirming the $\mathrm{pH}$ dependence on the adsorption process with the value of 5.5 in the determination of $\mathrm{pH}$ PzC in the present study. The interaction of the gypsum material with the metal ions pointed to chemisorption due to the best kinetics fit with the pseudo-second-order model. The value of the average energy of sorption (E) of D-R greater than $8 \mathrm{~kJ} \mathrm{~mol}^{-1}$. Furthermore, we concluded that that the removal of $\mathrm{Cd}$ moieties which did not undergo any treatment could be used as a potential $\mathrm{Cd}$ adsorbent. It is an effective tool in the remediation of environmental compartments contaminated by toxic heavy metals. We further recommend analyzing the behavior of the mineral materials, subsequently investigating the adsorption capacity with industrial effluents for different categories of metals.

\section{Funding}

This research received no external funding.

\section{Acknowledgments}

This research has no acknowledgment.

\section{Conflicts of Interest}

The authors declare no conflict of interest.

\section{References}

1. Gray, C.W.; Dunham, S.J.; Dennis, P.G.; Zhao, F.J.; McGrath, S.P. Field evaluation of in situ remediation of a heavy metal contaminated soil using lime and red-mud. Environ. Pollut. 2006, 142, 530-539, https://doi.org/10.1016/j.envpol.2005.10.017

2. Cheng, S.-F.; Hseu, Z.-Y. In-Situ Immobilization of Cadmium and Lead by Different Amendments in Two Contaminated Soils. Water, Air, Soil Pollut. 2002, 140, 73-84,https://doi.org/10.1023/A:1020132106541 
3. Volesky, B. Biosorption and biosorbents. Biosorption of heavy metals 1990.

4. Alkorta, I.; Hernández-Allica, J.; Becerril, J.M.; Amezaga, I.; Albizu, I.; Garbisu, C. Recent Findings on the Phytoremediation of Soils Contaminated with Environmentally Toxic Heavy Metals and Metalloids Such as Zinc, Cadmium, Lead, and Arsenic. Reviews in Environmental Science and Biotechnology 2004, 3, 71-90, https://doi.org/10.1023/B:RESB.0000040059.70899.3d

5. Geffner, L.F.; Santacruz, P.; Izurieta, M.; Flor, L.; Maldonado, B.; Auad, A.H.; Montenegro, X.; Gonzalez, R.; Silva, F. Administration of autologous bone marrow stem cells into spinal cord injury patients via multiple routes is safe and improves their quality of life: comprehensive case studies. Cell Transplant. 2008, 17, 1277-1293,https://doi.org/10.3727\%2F096368908787648074.

6. Kurniawan, T.A.; Babel, S. A research study on Cr (VI) removal from contaminated wastewater using lowcost adsorbents and commercial activated carbon. 2003; 1110-1117.

7. Shim, J.; Lee, S.M.; Rhee, B.S.; Ryu, S.K. Adsorption of Ni (II), Cu (II), Cr (VI) from multicomponent aqueous solution by pitch-based ACF. Extended abstracts. British Carbon Group 1996.

8. Ouki, S.K.; Neufeld, R.D. Use of activated carbon for the recovery of chromium from industrial wastewaters. J. Chem. Technol. Biotechnol. 1997, 70, 3-8.

9. Kadirvelu, K.; Thamaraiselvi, K.; Namasivayam, C. Adsorption of nickel(II) from aqueous solution onto activated carbon prepared from coirpith. Sep. Purif. Technol. 2001, 24, 497505,https://doi.org/10.1016/S1383-5866(01)00149-6.

10. Williams, C.J.; Aderhold, D.; Edyvean, R.G.J. Comparison Between Biosorbents For The Removal Of Metal Ions From Aqueous Solutions. Water Res. 1998, 32, 216-224,https://doi.org/10.1016/S00431354(97)00179-6.

11. Purkayastha, D.; Mishra, U.; Biswas, S. A comprehensive review on Cd(II) removal from aqueous solution. Journal of Water Process Engineering 2014, 2, 105-128, https://doi.org/10.1016/j.jwpe.2014.05.009.

12. Bailey, S.E.; Olin, T.J.; Bricka, R.M.; Adrian, D.D. A review of potentially low-cost sorbents for heavy metals. Water Res. 1999, 33, 2469-2479, https://doi.org/10.1016/S0043-1354(98)00475-8.

13. Xian, X. Effect of chemical forms of cadmium, zinc, and lead in polluted soils on their uptake by cabbage plants. Plant Soil 1989, 113, 257-264,https://doi.org/10.1007/BF02280189.

14. Rauta, C.; Lacatusu, R.; Cârstea, S. Heavy metal pollution of soils in Romania. Analele Institutului de Cercetari pentru Pedologie si Agrochimie-1993 (Romania) 1996.

15. Ma, L.Q.; Rao, G.N. Chemical Fractionation of Cadmium, Copper, Nickel, and Zinc in Contaminated Soils. J. Environ. Qual. 1997, 26, 259-264, https://doi.org/10.2134/jeq1997.00472425002600010036x.

16. Boon, D.Y.; Soltanpour, P.N. Lead, Cadmium, and Zinc Contamination of Aspen Garden Soils and Vegetation. J. Environ. Qual. 1992, 21, 82-86, https://doi.org/10.2134/jeq1992.00472425002100010012x.

17. Levy, D.B.; Barbarick, K.A.; Siemer, E.G.; Sommers, L.E. Distribution and Partitioning of Trace Metals in Contaminated Soils near Leadville, Colorado. J. Environ. Qual. 1992, 21, 185195,https://doi.org/10.2134/jeq1992.00472425002100020006x.

18. Friesen, C.; Herr, I.; Krammer, P.H.; Debatin, K.-M. Involvement of the CD95 (APO-1/Fas) receptor/ligand system in drug-induced apoptosis in leukemia cells. Nat. Med. 1996, 2, 574577,https://doi.org/10.1038/nm0596-574.

19. Jung, M.C.; Thornton, I. Environmental contamination and seasonal variation of metals in soils, plants and waters in the paddy fields around a $\mathrm{Pb}-\mathrm{Zn}$ mine in Korea. Sci. Total Environ. 1997, 198, 105-121, https://doi.org/10.1016/S0048-9697(97)05434-X.

20. Narwal, R.P.; Singh, B.R. Effect of Organic Materials on Partitioning, Extractability and Plant Uptake of Metals in an Alum Shale Soil. Water, Air, Soil Pollut. 1998, 103, 405421,https://doi.org/10.1023/A:1004912724284.

21. Simoes Mimura, A.M.; de Almeida Vieira, T.V.; Martelli, P.B.; Gorgulho, H.d.F. Utilization Of Rice Husk To Remove $\mathrm{Cu} 2+, \mathrm{Al} 3+, \mathrm{Ni} 2+$ And $\mathrm{Zn} 2+$ From Wastewater. Quim. Nova 2010, 33, 12791284,http://dx.doi.org/10.1590/S0100-40422010000600012.

22. Montanher, S.F.; Oliveira, E.A.; Rollemberg, M.C. Removal of metal ions from aqueous solutions by sorption onto rice bran. J. Hazard. Mater. 2005, 117, 207-211,https://doi.org/10.1016/j.jhazmat.2004.09.015.

23. Farooq, U.; Khan, M.A.; Athar, M.; Kozinski, J.A. Effect of modification of environmentally friendly biosorbent wheat (Triticum aestivum) on the biosorptive removal of cadmium(II) ions from aqueous solution. Chem. Eng. J. 2011, 171, 400-410,https://doi.org/10.1016/j.cej.2011.03.094.

24. Witek-Krowiak, A.; Szafran, R.G.; Modelski, S. Biosorption of heavy metals from aqueous solutions onto peanut shell as a low-cost biosorbent. Desalination 2011, 265, 126134,https://doi.org/10.1016/j.desal.2010.07.042.

25. Ho, Y.S.; McKay, G. Pseudo-second order model for sorption processes. Process Biochem. 1999, 34, 451465,https://doi.org/10.1016/S0032-9592(98)00112-5.

26. Santos, V.C.G.D.; Tarley, C.R.T.; Caetano, J.; Dragunski, D.C. Assessment of chemically modified sugarcane bagasse for lead adsorption from aqueous medium. Water Sci. Technol. 2010, 62, 457465,https://doi.org/10.2166/wst.2010.291. 
27. Azouaou, N.; Sadaoui, Z.; Djaafri, A.; Mokaddem, H. Adsorption of cadmium from aqueous solution onto untreated coffee grounds: Equilibrium, kinetics and thermodynamics. J. Hazard. Mater. 2010, 184, 126-134, https://doi.org/10.1016/j.jhazmat.2010.08.014.

28. Sun, S.; Yu, Q.; Li, M.; Zhao, H.; Wu, C. Preparation of coffee-shell activated carbon and its application for water vapor adsorption. Renewable Energy 2019, 142, 11-19,https://doi.org/10.1016/j.renene.2019.04.097.

29. Chambers, J.C.; Sidle, R.C. Fate of Heavy Metals in an Abandoned Lead-Zinc Tailings Pond: I. Vegetation. J. Environ. Qual. 1991, 20, 745-751,https://doi.org/10.2134/jeq1991.00472425002000040005x.

30. Mazlan, M.A.F.; Uemura, Y.; Yusup, S.; Elhassan, F.; Uddin, A.; Hiwada, A.; Demiya, M. Activated Carbon from Rubber Wood Sawdust by Carbon Dioxide Activation. Procedia Engineering 2016, 148, 530537,https://doi.org/10.1016/j.proeng.2016.06.549.

31. Wang, J.Y.; Wang, R.Z.; Wang, L.W. Water vapor sorption performance of ACF-CaCl2 and silica gel-CaCl2 composite adsorbents. Appl. Therm. Eng. 2016, 100, 893901,https://doi.org/10.1016/j.applthermaleng.2016.02.100.

32. Uzun, B.B.; Yaman, E. Pyrolysis kinetics of walnut shell and waste polyolefins using thermogravimetric analysis. Journal of the Energy Institute 2017, 90, 825-837,https://doi.org/10.1016/j.joei.2016.09.001.

33. Badgley, B.D.; Steele, M.K.; Cappellin, C.; Burger, J.; Jian, J.; Neher, T.P.; Orentas, M.; Wagner, R. Fecal indicator dynamics at the watershed scale: Variable relationships with land use, season, and water chemistry. Sci. Total Environ. 2019, 697, 134113,https://doi.org/10.1016/j.scitotenv.2019.134113.

34. Gao, X.; Wu, L.; Li, Z.; Xu, Q.; Tian, W.; Wang, R. Preparation and characterization of high surface area activated carbon from pine wood sawdust by fast activation with H3PO4 in a spouted bed. J. Mater. Cycles Waste Manage. 2018, 20, 925-936, https://doi.org/10.1007/s10163-017-0653-x.

35. Shahkarami, S.; Azargohar, R.; Dalai, A.K.; Soltan, J. Breakthrough CO2 adsorption in bio-based activated carbons. Journal of Environmental Sciences 2015, 34, 68-76,https://doi.org/10.1016/j.jes.2015.03.008.

36. Sultan, M.; El-Sharkawy, I.I.; Miyazaki, T.; Saha, B.B.; Koyama, S. An overview of solid desiccant dehumidification and air conditioning systems. Renewable and Sustainable Energy Reviews 2015, 46, 1629,https://doi.org/10.1016/j.rser.2015.02.038.

37. Taer, E.; Deraman, M.; Talib, I.A.; Umar, A.A.; Oyama, M.; Yunus, R.M. Physical, electrochemical and supercapacitive properties of activated carbon pellets from pre-carbonized rubber wood sawdust by $\mathrm{CO} 2$ activation. Current Applied Physics 2010, 10, 1071-1075,https://doi.org/10.1016/j.cap.2009.12.044.

38. Ding, X.; Chen, S.; Zhang, B.; Liang, C.; He, H.; Horwath, W.R. Warming increases microbial residue contribution to soil organic carbon in an alpine meadow. Soil Biology and Biochemistry 2019, 135, 13-19, https://doi.org/10.1016/j.soilbio.2019.04.004.

39. Atere, C.T.; Gunina, A.; Zhu, Z.; Xiao, M.; Liu, S.; Kuzyakov, Y.; Chen, L.; Deng, Y.; Wu, J.; Ge, T. Organic matter stabilization in aggregates and density fractions in paddy soil depending on long-term fertilization: Tracing of pathways by 13C natural abundance. Soil Biology and Biochemistry 2020, 149, 107920-107931, https://doi.org/10.1016/j.soilbio.2020.107931.

40. Liu, Y.; Hu, C.; Hu, W.; Wang, L.; Li, Z.; Pan, J.; Chen, F. Stable isotope fractionation provides information on carbon dynamics in soil aggregates subjected to different long-term fertilization practices. Soil and Tillage Research 2018, 177, 54-60, https://doi.org/10.1016/j.still.2017.11.016.

41. Li, J.; Yuan, X.; Ge, L.; Li, Q.; Li, Z.; Wang, L.; Liu, Y. Rhizosphere effects promote soil aggregate stability and associated organic carbon sequestration in rocky areas of desertification. Agriculture, Ecosystems \& Environment 2020, 304, 107117-107126, https://doi.org/10.1016/j.agee.2020.107126.

42. Balasubramanian, D.; Zhang, Y.-P.; Grace, J.; Sha, L.-Q.; Jin, Y.; Zhou, L.-G.; Lin, Y.-X.; Zhou, R.-W.; Gao, J.-B.; Song, Q.-H.; Liu, Y.-T.; Zhou, W.-J. Soil organic matter as affected by the conversion of natural tropical rainforest to monoculture rubber plantations under acric ferralsols. Catena 2020, 195, 1047549104753, https://doi.org/10.1016/j.catena.2020.104753.

43. 36. Deng, Q.; Zhang, D.; Han, X.; Chu, G.; Zhang, Q.; Hui, D. Changing rainfall frequency rather than drought rapidly alters annual soil respiration in a tropical forest. Soil Biology and Biochemistry 2018, 121, 8-15, https://doi.org/10.1016/j.soilbio.2018.02.023.

44. Volk, M.; Bassin, S.; Lehmann, M.F.; Johnson, M.G.; Andersen, C.P. 13C isotopic signature and C concentration of soil density fractions illustrate reduced $\mathrm{C}$ allocation to subalpine grassland soil under high atmospheric N deposition. Soil Biology and Biochemistry 2018, 125, 178-184, https://doi.org/10.1016/j.soilbio.2018.07.014.

45. Badgley, B.D.; Steele, M.K.; Cappellin, C.; Burger, J.; Jian, J.; Neher, T.P.; Orentas, M.; Wagner, R. Fecal indicator dynamics at the watershed scale: Variable relationships with land use, season, and water chemistry. Science of The Total Environment 2019, 697, https://doi.org/10.1016/j.scitotenv.2019.134113.

46. Zhang, C.; Liu, Y.; Li, X.; Chen, H.; Wen, T.; Jiang, Z.; Ai, Y.; Sun, Y.; Hayat, T.; Wang, X. Highly uranium elimination by crab shells-derived porous graphitic carbon nitride: Batch, EXAFS and theoretical calculations. Chemical Engineering Journal 2018, 346, 406-415, https://doi.org/10.1016/j.cej.2018.03.186.

47. Cui, H.; Zhang, S.; Li, R.; Yi, Q.; Zheng, X.; Hu, Y.; Zhou, J. Leaching of Cu, Cd, Pb, and phosphorus and their availability in the phosphate-amended contaminated soils under simulated acid rain. Environmental Science and Pollution Research 2017, 24, 21128-21137, https://doi.org/10.1007/s11356-017-9696-8. 
48. Shi, R.-Y.; Hong, Z.-N.; Li, J.-Y.; Jiang, J.; Baquy, M.A.-A.; Xu, R.-K.; Qian, W. Mechanisms for Increasing the $\mathrm{pH}$ Buffering Capacity of an Acidic Ultisol by Crop Residue-Derived Biochars. Journal of Agricultural and food chemistry 2017, 65, 8111-8119, https://doi.org/10.1021/acs.jafc.7b02266.

49. Meyer, N.; Welp, G.; Amelung, W. Effect of sieving and sample storage on soil respiration and its temperature sensitivity (Q10) in mineral soils from Germany. Biology and Fertility of Soils 2019, 55, 825832, https://doi.org/10.1007/s00374-019-01374-7.

50. Nguyen, T.; Tran, T.T.H. The Contribution of Various Components to pH Buffering Capacity of Acrisols in Southeastern Vietnam. Communications in Soil Science and Plant Analysis 2019, 50, 1170-1177, https://doi.org/10.1080/00103624.2019.1604735.

51. Delgado-Baquerizo, M.; Oliverio, A.M.; Brewer, T.E.; Benavent-González, A.; Eldridge, D.J.; Bardgett, R.D. Maestre, F.T.; Singh, B.K.; Fierer, N. A global atlas of the dominant bacteria found in soil 2018, 359, 320- 325, https://doi.org/10.1126/science.aap9516 